\title{
DERIVATIONAL AND INFLECTIONAL MORPHEMES ON JOKO WIDODO'S SPEECH FOR ENGLISH EDUCATION
}

\author{
Septa Aryanika $^{1^{*}}$, Ratih Henisah ${ }^{2}$, Dewi Kurniawati ${ }^{1}$, Is Susanto ${ }^{1}$ \\ ${ }^{1}$ UIN Raden Intan Lampung \\ ${ }^{2}$ Universitas Negeri Yogyakarta \\ septaaryanika@radenintan.ac.id
}

\begin{abstract}
This study aims to determine the frequency and process of derivational and inflectional morphemes in Joko Widodo's speech at the Asian Pacific Economic Cooperation summit. The study used descriptive qualitative analysis methods. The data were analyzed using Fromkin's principle. The data analysis yielded 133 terms made up of derivational and inflectional morphemes. Derivational morphemes accounted for 50.37 percent of all occurrences in this study, while inflectional morphemes accounted for 49.63 percent. The researchers discovered several derivation processes that modify grammatical classes while remaining unchanged, such as noun form, adjective form, verb form, adverb form, adjective form, noun to noun, and adjective to adjective. In this study, five types of Inflectional morphemes were found: -s (plural and thirdperson singular), -ing (progressive), -ed (past tense), and -er (comparative). Morphemes are an important feature of language so it is important for students to learn in school, especially for language learners. Morphological awareness, which we describe as a basic understanding of the morphemic structure of words, is required of the learner. Finally, the implications of this research will be an inspiration for further research in morphological processing, especially regarding derivational and inflectional morphemes.
\end{abstract}

Key words: derivational, inflectional morphemes, morphology, word identification

\section{A. INTRODUCTION}

One of the goals of studying morphology theory is to be able to characterize the morphological structure and the relationship of words in the language of the speakers. The ability to understand and create new words consisting of familiar parts is clearly an important component of linguistic competence, referring to knowledge of the morphology of language. While morphological theory aims to characterize what speakers know about the relationship between words, pronunciation models and also 
to debate whether morphological information plays a role in producing or recognizing words. Understanding basic morphology and having a corpus of morphemes can help in decoding and comprehending meanings, especially for multisyllabic words (Carlisle, 2003). A morpheme is the smallest meaningful unit in a word. Morphemes are phonological, semantic/syntactic, and syntactic units. Holly B. Lane, Linda Gutlohn \& Wilhelmina van Dijk (2019) point out: "Knowledge of morphemes, the smallest meaningful units within words, contributes to word reading skills, vocabulary, and text comprehension" (p.1). When learners learn a foreign language, it is essential to master vocabulary. If students have a great deal of vocabulary, the significance of the new word students have learned is easier to learn and understand. Previous studies have reported the correlation between morphological knowledge and vocabulary (e.g., Goodwin, Petscher, Carlisle, \& Mitchell, 2017; Tighe \& Schatschneider, 2015). Inflection, derivation, and compounding are the three types of morphological processes identified by lexical morphology theories (Carlisle, 2004).

Derivational affixes are morphemes that descend from or produce new words by transforming points in the language. Bauer defines a derivational morpheme is one that delivers a new lexeme from a root. The morphemes that do not make a recent argument are known as inflectional morphemes. Readers would be able to greatly expand their vocabulary until they can distinguish derivational and inflectional affixes. It would be easier for us to learn a new language and grasp the sense of language if we have a large or sufficient vocabulary. It is important for students studying a foreign language to learn vocabulary because a lack of vocabulary makes it difficult to grasp the meaning of the language. There are a variety of ways to expand our vocabulary. For example, you might read a book or novel, listen to international music, or watch a movie. The researchers analyzed the video of Joko Widodo's speech at the APEC CEO Summit Asian Pacific for this report. The researchers just looked at his speech at APEC because it was one of the first official speeches delivered by President Jokowi after he was inaugurated as president, and it was one of the first speeches that followed an object and used the English language. Joko Widodo has influenced Indonesians as president, 
as shown by his voice. It is essential to consider because as president the confidence, interest, loyalty, and respect should be intaken by Indonesia. Based on Fromkin's theory, the researchers wanted to find the frequency of derivational and inflectional morphemes, as well as the mechanism of derivational and inflectional morphemes, in President Joko Widodo's speech at the APEC.

The researchers were aware that this was not the first study in the area of linguistics. The previous studies have investigated the role of morphemes in word production of writing text and reading, but in this article present the result of our investigation in word production of speech text.

\section{B. LITERATURE REVIEW}

\section{Bound Morpheme}

Bound morpheme is a dependent morpheme because it cannot stand alone. Bound morpheme is the forms that cannot ordinarily stand alone and are usually attached to another form (Yule, 2010). It underlines that a bound morpheme cannot stand alone in a language as a freely pronounceable word but does involve the existence of other morphemes. Bound morphemes in English include -ed "past," -s plural (more than one), re- (again, back), and mis- (wrongly). None of these types are ever pronounced by an English speaker on their own. They are still connected to certain morphemes and can be found in words like kill-ed, dog-s, re-write, and mis-hear.

As we know, bound morphemes are also known as affixes. Affixation is the act of attaching or joining a connected morpheme to a base before, after, or within it. Prefixes, infixes, and suffixes are the three types of affixes. There is no infix in English (Nurjannah, 2018). It can be inferred from the examples given above that all affixes (suffixes and prefixes) are bound morphemes. Suffixes are attached to the base at the back, while prefixes are attached at the front. In other terms, suffixes and prefixes are words that are added before and after a word to form a new word. Then there are two kinds of bound morphemes: derivational and inflectional morphemes. 


\section{Derivational Morphemes}

The derivational morpheme is the word-formation that can add suffixes or affixes that can change the meaning and word class. Derivational morphemes can alter the grammatical category phrase (Yule, 2014). Some morphemes derive or generate a new word by modifying its meaning, such as happy- happiness (it has meaning feeling pleasure or containment - the state of feeling pleasure or containment). Since -nees is a suffix, most derivational suffixes can modify the syntactic category as well as the context. Just a few remain in the same syntactic group.

Derivational morphemes are affixes in English (prefixes or suffixes). Prefixes, infixes, and suffixes are all affixes in general, but there is no infix in English. In English, all prefixes are derivational. In English, all prefixes change the meaning, but they don't change the syntactic category. When a form adds meaning by derivational affixes, it adds meaning (Fromkin et al., 2017). These derived words may perform a variety of grammatical functions or simply create new words without modifying the part of the expression.

Based on Fromkin, Hyams and Rodman (2017) and the supporting statements above, the researchers should conclude that adding affixes (prefix and suffix) does not alter the word class of all derived terms. Such derivational affix processes that modify the syntactic type are: noun to adjective, verb to noun, adjective to adverb, noun to verb, adjective to noun, verb to adjective, noun to adverb, adjective to noun, verb to adjective, noun to adverb, adjective to verb. Some derivational affix processes do not result in a shift in grammatical classes: noun to noun, verb to verb, and adjective to adjective. Thus, regarding the theory of Fromkin, et al. (2017) and statements from some experts, the researchers can infer that by adding the prefix and suffix, the derivational morpheme can take on new meaning and modify the word class.

\section{Inflectional Morphemes}


In inflection, the way a word is changed to represent things like tense, plurality, gender, and so on, is generally regulated by consistent, predictable rules known as regular inflection, which includes verbs, nouns, and adjectives. The grammatical category of the word to which they are attached is never changed by inflectional morphemes. It simply means that they simplify and include additional grammatical detail regarding the context of words to which they are attached. It's also possible to use an inflectional morpheme. Fromkin et al. (2017), inflectional definitions in language are severely limited: "the majority of them fall under the general headings of tense, number, human, and so on.".

Another supporting argument came from Bauer (1988) who noted that "inflectional morphemes are those that do not generate new meaning." The syntactic category of the words or morphemes to which they are connected is never changed by these morphemes. They merely add a grammatical class. It frequently employs the words "intense," "number," and "comparison." We should know what tenses are used in a sentence, such as the present, past, and future, when it uses sentences. When we talk about the present, we're talking about something that happened now, as indicated by the suffix s/es, and when we talk about the past, we're talking about something that happened in the past, as indicated by the suffix -ed. When talking about plural, we must add suffixes - like cows, dogs and chairs - even discuss the number in singular and plural in inflection morphemes. The analogy is often used in inflectional morphemes, such as tall=taller, which is added by the suffix -er and is referred to as comparative in one letter, beautiful=more beautiful, which is referred to as comparative in three terms. Inflectional morphemes use the word superlative.

Inflectional morphemes never modify the grammatical category of the stems to which they are attached, which is not the case for derivational morphemes. In addition, Yule (2014) noted that inflectional affixes are part of a bound morpheme that does not work to create new words in the language, but rather to indicate the grammatical function of words, such as the use of singular or plural, past tense, or not, comparative or 
possessive, and so on. The use of -ed to leap into the past, tense forms, and use of-s to make the word boy into plural boys are examples of inflectional morphemes at work. The — ing, — s, — est, and — are several other examples, as Myrna's phrases sing, she sings, the smaller one, the smaller ones, and Myrna's horse.

Inflectional morphemes often have a description of meaning or a part of speech, only refining the existing meaning and providing additional grammatical detail. In contrast to derivative morphemes, the grammatical category of the form they are connected with never changes. There are many types of daily inflection morpheme processes (Fromkin et al, 2017); She waits at home (simple present, the subject is the third singular). She wait-ed at home (past tense). She is learn-ing English (Progressive). Past participle : Mary has eat-en the donuts. Plural marker : She ate the donut-s. Possessive : Disa's hair is short. Comparative: Disa has short-er hair than Karin. Superlative :Disa has the short-est hair

Inflectional represent connections between various parts of a sentence. As the -s at the bottom of the verb is a symbol of agreement, the verb is a third person and is unique and that verb is present. The suffix -ed implies a tense past, -ing reflects a connection between speaking time (e.g. now) and event time. -en imply the participle in the past and is expected to use the syntactic language rules with verbs. -s shows singular and plural numbers. - it reveals ownership as a possessive case. A noun can be transformed from a simple person, location, or thing to a person, place, or thing that owns something by adding's (or sometimes just the apostrophe). Comparative and superlative cases are indicated by the suffixes -er and - est.

Thus, based on Fromkin's theory and statements from some experts, we may infer that inflectional is a form of bound morpheme that does not alter the word's class and only indicates the grammatical role of words by adding the suffix.

\section{Important of Morpheme in Learning English}


English language is not only phonetic but also is completely morpho-phonetic, both phonemes and morphemes are appeared in the spelling system. Powerful morphological knowledge can help students decode, spell, pronounce, and figure out the meaning of unknown words, and comprehend larger passages. Morphemes and English learning are like two indivisible coins, both are closely related, the better the students' English skills, the better the use of morphemes in understanding unknown words (Anglin, 1993). Both derivational and inflectional morphemes must be mastered by the students.

\section{METHOD OF THE STUDY}

This research used descriptive qualitative as the design of the research because the researchers accumulated the data, applied an analysis, created a finding, and got the result. Qualitative research tries to find out meaning, examine the process, and to get insight into a great detailed understanding of an individual, group, or situation (Lodico et. al., 2006), A descriptive qualitative study was aimed to record an event, situation, or circumstance. In other words, qualitative analysis is more focusing on information received by researchers in descriptive text.

Data took from one the Joko Widodo's speech at the APEC ASEAN Pacific CEO Summit was collected from the present report. The researchers found out the frequency of occurrence of derivational and inflectional morpheme and identified the process of derivational and inflectional morpheme in President Joko Widodo's speech at APEC. The researchers analyzed a transcript of the speech to determine the frequency of derivational and inflectional morpheme occurrences and to explain the derivational and inflectional morpheme mechanism. In analyzing the data, three phases had been used; data condensation, data display, and conclusion drawing or verification (Miles and Huberman, 2014).

\section{Data condensation;}

To find out the occurrence frequency of derivational and inflectional affixes and to describe the process of derivational and inflectional affixes from the 
English Education: Jurnal Tadris Bahasa Inggris pISSN 2086-6003 | eISSN 2580-1449 Vol 14 (2), 2021, 238-256

speech of Joko Widodo's at APEC CEO summit ASEAN pacific. The data was the transcript of Joko Widodo's Speech At APEC CEO Summit ASEAN Pacific on YouTube.

\section{Data Display}

The data that has been reduced is then described as research data containing the occurrence frequency of derivational and inflectional morphemes and describes the process on the table form. Then data were calculated by using the formula :

$$
\mathrm{P}=\frac{F}{N} x 100
$$

Note:

$\mathrm{P}=$ Percentage

$\mathrm{F}=$ Frequency

$\mathrm{N}=$ Number of cases

\section{Conclusion Drawing or Verification}

Then, the researcher concluded the occurrence frequency of derivational and inflectional affixes and described the process of derivational and inflectional morphemes found on Joko Widodo's speech at APEC CEO Summit ASEAN Pacific.

\section{RESULT}

Based on the research, the objectives of the research were to know the occurrence frequency and process of derivational and inflectional morphemes on Joko Widodo speech based on Fromkin, et al's theory. The meaning of derivational morphemes are bound morphemes that may change the grammatical class or they just produce new words by adding prefixes or suffixes without changing the grammatical class. Whereas, inflectional morphemes are bound morphemes that don't change the grammatical class or only indicate the grammatical function of words

The data collection of this research was taken from Joko Widodo's speech text below: 
English Education: Jurnal Tadris Bahasa Inggris pISSN 2086-6003 | eISSN 2580-1449

Vol 14 (2), 2021, 238-256

Table 1. Finding the data in the Occurrence Frequency and Process Derivational and Inflectional Morphemes

\begin{tabular}{|c|c|c|c|c|c|c|}
\hline \multirow{2}{*}{ No } & \multirow{2}{*}{ Word } & \multirow{2}{*}{ Base } & \multicolumn{2}{|c|}{ Affixes } & \multirow{2}{*}{ DM } & \multirow{2}{*}{$\mathbf{I M}$} \\
\hline & & & Prefix & Suffix & & \\
\hline 1. & Ladies & Lady & & -es & & Noun-Noun \\
\hline 2. & Gentleman & Gentle & & - man & Adjective - Noun & \\
\hline 3. & CEOs & CEO & & $-S$ & & Noun-Noun \\
\hline 4. & Behalf & Half & $\mathrm{Be}-$ & & Noun - Noun & \\
\hline 5. & Indonesian & Indonesia & & $-n$ & Noun - Noun & \\
\hline 6. & Government & Govern & & - ment & Verb - Noun & \\
\hline 7. & Coming & Come & & -ing & Verb - Noun & \\
\hline 8. & Presentation & Present & & -ion & Adjective - Noun & \\
\hline 9. & Businessman & Business & & $-\operatorname{man}$ & Noun - Noun & \\
\hline 10. & Years & Year & & $-s$ & & Noun-Noun \\
\hline 11. & Investment & Invest & & -ment & Verb - Noun & \\
\hline 12. & Shows & Show & & $-S$ & & Verb-Verb \\
\hline 13. & Population & Populate & & -ion & Verb - Noun & \\
\hline 14. & Distance & Distant & & - ce & Adjective - Noun & \\
\hline 15. & Imagine & Image & & -ine & Noun - Verb & \\
\hline 16. & Islands & Island & & $-\mathrm{s}$ & & Noun-Noun \\
\hline 17. & Islands & Island & & $-S$ & & Noun-Noun \\
\hline 18. & National & Nation & & -al & Noun - Adjective & \\
\hline 19. & Budget & Get & Bud- & & Verb - Noun & \\
\hline 20. & Consumption & Consume & & -ion & Noun - Noun & \\
\hline 21. & Productive & Produce & & -tive & Verb - Adjective & \\
\hline 22. & Activities & Activity & & -es & & Noun-Noun \\
\hline 23. & Consumptive & Consumpt & & -ive & Noun - Adjective & \\
\hline 24. & Activities & Activity & & -es & & Noun-Noun \\
\hline 25 . & Productive & Produce & & -tive & Verb - Adjective & \\
\hline 26. & Activities & Activity & & -es & & Noun-Noun \\
\hline 27. & Seeds & Seed & & $-s$ & & Noun-Noun \\
\hline 28. & Fertilizers & Fertilizer & & $-S$ & & Noun-Noun \\
\hline
\end{tabular}


English Education: Jurnal Tadris Bahasa Inggris pISSN 2086-6003 | eISSN 2580-1449

Vol 14 (2), 2021, 238-256

\begin{tabular}{|c|c|c|c|c|c|c|}
\hline 29. & Irrigation & Irrigate & & -ion & Verb - Noun & \\
\hline 30. & Dams & Dam & & $-s$ & & Noun-Noun \\
\hline 31. & Dams & Dam & & $-s$ & & Noun-Noun \\
\hline 32. & Years & Year & & $-s$ & & Noun-Noun \\
\hline 33. & Farming & Farm & & -ing & Verb - Noun & \\
\hline 34. & Engines & Engine & & $-s$ & & Noun-Noun \\
\hline 35. & Refrigerators & Refrigerator & & $-s$ & & Noun-Noun \\
\hline 36. & Increase & Crease & In- & & Noun - Verb & \\
\hline 37. & Income & Come & In- & & Verb - Noun & \\
\hline 38. & Enterprises & Enterprise & & $-s$ & & Noun-Noun \\
\hline 39. & Villages & Village & & $-s$ & & Noun-Noun \\
\hline 40. & Working & Work & & -ing & Verb - Noun & \\
\hline 41. & Education & Educate & & -ion & Verb - Noun & \\
\hline 42. & Infrastructure & Structure & -Infra & & Noun - Noun & \\
\hline 43. & Years & Year & & $-s$ & & Noun-Noun \\
\hline 44. & Seaports & Seaport & & $-s$ & & Noun-Noun \\
\hline 45. & Seaports & Seaport & & $-s$ & & Noun-Noun \\
\hline 46. & Islands & Island & & $-s$ & & Noun-Noun \\
\hline 47. & Seaports & Seaport & & $-s$ & & Noun-Noun \\
\hline 48. & Seaports & Seaport & & $-s$ & & Noun-Noun \\
\hline 49. & Opportunity & Opportune & & -ity & Adjective - Noun & \\
\hline 50. & Seaports & Seaport & & $-s$ & & Noun-Noun \\
\hline 51. & Seaports & Seaport & & $-s$ & & Noun-Noun \\
\hline 52. & Shows & Show & & $-s$ & & Verb-Verb \\
\hline 53. & Capacity & City & Capa - & & Noun - Noun & \\
\hline 54. & TEUs & TEU & & $-s$ & & Noun-Noun \\
\hline 55. & TEUs & TEU & & $-s$ & & Noun-Noun \\
\hline 56. & Potential & Potent & & -ial & Adjective - Adj & \\
\hline 57. & Ports & Port & & $-s$ & & Noun-Noun \\
\hline 58. & Opportunity & Opportune & & -ity & Adjective - Noun & \\
\hline 59. & Network & Work & Net- & & Verb - Noun & \\
\hline 60. & Already & Ready & Al- & & Adjective-Adverb & \\
\hline 61. & Opportunity & Opportune & & -ity & Adjective - Noun & \\
\hline 62. & Transportation & Transport & & -ion & Verb - Noun & \\
\hline
\end{tabular}


English Education: Jurnal Tadris Bahasa Inggris pISSN 2086-6003 | eISSN 2580-1449

Vol 14 (2), 2021, 238-256

\begin{tabular}{|c|c|c|c|c|}
\hline Transportation & Transport & -ion & Verb - Noun & \\
\hline Cities & City & -es & & Noun-Noun \\
\hline Started & Start & -ed & & Verb-Verb \\
\hline Opportunity & Opportune & -ity & Adjective - Noun & \\
\hline National & Nation & $-\mathrm{al}$ & Noun - Adjective & \\
\hline Budget & Bud- & & Verb - Noun & \\
\hline Limited & Limit & -ed & Noun - Adjective & \\
\hline Transportation & Transport & -ion & Verb - Noun & \\
\hline Transportation & Transport & -ion & Verb - Noun & \\
\hline Lower & Low & -er & & Adjective- Adj \\
\hline Transportation & Transport & -ion & Verb - Noun & \\
\hline Vessels & Vessel & $-\mathrm{s}$ & & Noun-Noun \\
\hline Vessels & Vessel & $-\mathrm{s}$ & & Noun-Noun \\
\hline Transportation & Transport & -ion & Verb - Noun & \\
\hline Example & Exam & -ple & Noun - Noun & \\
\hline Imagine & Image & -ine & Noun - Verb & \\
\hline Times & Time & $-\mathrm{s}$ & & Noun-Noun \\
\hline Islands & Island & $-s$ & & Noun-Noun \\
\hline Electricity & Electric & -ity & Adjective - Noun & \\
\hline Plants & Plant & $-\mathrm{s}$ & & Noun-Noun \\
\hline Megavolts & Megavolt & $-\mathrm{s}$ & & Noun-Noun \\
\hline Industries & Industry & -es & & Noun-Noun \\
\hline Projects & Project & $-\mathrm{s}$ & & Noun-Noun \\
\hline Industrial & Industry & -al & Noun - Adjective & \\
\hline Zones & Zone & $-\mathrm{s}$ & & Noun-Noun \\
\hline Manufacturing & Manufacture & -ing & Verb - Noun & \\
\hline Zones & Zone & $-s$ & & Noun-Noun \\
\hline Plants & Plan & $-\mathrm{s}$ & & Noun-Noun \\
\hline Opportunity & Opportune & -ity & Adjective - Noun & \\
\hline Plants & Plant & $-\mathrm{s}$ & & Noun-Noun \\
\hline Manufacturing & Manufacture & -ing & Verb - Noun & \\
\hline Industrial & Industry & $-\mathrm{al}$ & Noun- Adjective & \\
\hline Zones & Zone & $-\mathrm{s}$ & & Noun-Noun \\
\hline Investors & Investor & $-s$ & & Noun-Noun \\
\hline
\end{tabular}


English Education: Jurnal Tadris Bahasa Inggris pISSN 2086-6003 | eISSN 2580-1449

Vol 14 (2), 2021, 238-256

\begin{tabular}{|c|c|c|c|c|c|c|}
\hline 97. & Investors & Investor & & $-s$ & & Noun-Noun \\
\hline 98. & Acquisition & Acquisitive & & -ion & Adjective - Noun & \\
\hline 99. & Ministers & Minister & & $-s$ & & Noun-Noun \\
\hline 100. & Governors & Govern & & $-s$ & & Noun-Noun \\
\hline 101. & Mayors & Mayor & & $-s$ & & Noun-Noun \\
\hline 102. & Clearing & Clear & & -ing & Verb - Noun & \\
\hline 103. & Acquisition & Acquisitive & & -ion & Adjective - Noun & \\
\hline 104. & Governor & Govern & & -or & Verb - Noun & \\
\hline 105. & Farmer & Farm & & -er & Noun - Noun & \\
\hline 106. & Started & Start & & -ed & & Verb-Verb \\
\hline 107. & Years & Year & & $-s$ & & Noun-Noun \\
\hline 108. & Stopped & Stop & & -ed & & Verb-Verb \\
\hline 109. & Years & Year & & $-s$ & & Noun-Noun \\
\hline 110. & Kilometers & Kilometer & & $-\mathrm{s}$ & & Noun-Noun \\
\hline 111. & Unfinished & Finish & Un- & -ed & Verb - Adjective & \\
\hline 112. & Families & Family & & -es & & Noun-Noun \\
\hline 113. & Compensation & Compensate & & -ion & Verb - Noun & \\
\hline 114. & Times & Time & & $-s$ & & Noun-Noun \\
\hline 115. & Times & Time & & $-s$ & & Noun-Noun \\
\hline 116. & Times & Time & & $-\mathrm{s}$ & & Noun-Noun \\
\hline 117. & Meeting & Meet & & -ing & Verb - Noun & \\
\hline 118. & Cleared & Clear & & -ed & & Verb-Verb \\
\hline 119. & Used & Use & & -ed & & Verb-Verb \\
\hline 120. & National & Nation & & $-\mathrm{al}$ & Noun - Adjective & \\
\hline 121. & Service & Serve & & -ce & Verb - Noun & \\
\hline 122. & Facilitate & Facility & & -ity & Noun - Verb & \\
\hline 123. & Example & Exam & & -ple & Noun - Noun & \\
\hline 124. & Needs & Need & & $-\mathrm{s}$ & & Verb-Verb \\
\hline 125. & Days & Day & & $-s$ & & Noun-Noun \\
\hline 126. & Finally & Final & & $-1 y$ & Adjective -Adverb & \\
\hline 127. & Behalf & Half & $\mathrm{Be}-$ & & Noun - Noun & \\
\hline 128. & Indonesian & Indonesia & & $-n$ & Noun - Noun & \\
\hline 129. & Government & Govern & & -ment & Verb - Noun & \\
\hline 130. & Listening & Listen & & -ing & Verb - Noun & \\
\hline
\end{tabular}


English Education: Jurnal Tadris Bahasa Inggris pISSN 2086-6003 | eISSN 2580-1449 Vol 14 (2), 2021, 238-256

$\begin{array}{llllll}\text { 131. } & \text { Presentation } & \text { Present } & \text {-ion } & \text { Adjective - Noun } & \\ \text { 132. } & \text { Waiting } & \text { Wait } & \text {-ing } & \text { Verb-Verb } \\ \text { 133. } & \text { Waiting } & \text { Wait } & \text {-ing } & \text { Verb-Verb }\end{array}$

Derivational affixes indicated that there were 27 affixes, 8 prefixes and 19 suffixes. The prefixes were be-, infra-, capa-, bud-, in-, net-, un- and al-. Then the suffixes were -ed, -man, -ation, -ity, -ion, -ing, -n, -al, -ive, -ment, -or, -ice, -ce, -ine, -ate, -ly, -ple and-er. While, inflectional affixes indicate that there were 5 suffixes, the suffixes were $-\mathrm{s}$, -es, -ed, -ing and -er. Suffix $-\mathrm{s}$ for progressive form, $-\mathrm{s} /-\mathrm{es}$ for $3^{\text {rd }}$ person singular, -ed for past tense, -ing for progressive form, and -er for comparative form. In contrast, the types of the inflectional suffix of -en for past participle and -est for superlative form were not found on the speech of Joko Widodo being analyzed.

Table 2. The percentage of Occurrence Frequency Derivational and Inflectional Morphemes

\begin{tabular}{llll}
\hline No & Type of Boun Morphemes & amount & percentage \\
\hline 1 & Derivational Morphemes & 67 & $50.37 \%$ \\
2. & Inflectional Morphemes & 66 & $49,63 \%$ \\
Toral & & I33 & $100 \%$
\end{tabular}

Based on the analysis data the findings and descriptions of occurrence frequency of derivational and inflectional indicate the first percentage came to 67 of 133 items from Joko Widodo's speech, the total occurrence frequency of derivational morphemes were $50.37 \%$. Then, the percentage occurrence frequency of inflectional morphemes was $49.63 \%$, which came to 66 of 133 items from Joko Widodo's speech. Based on the percentage above, derivational morpheme was the most occurrence frequency on the speech of Joko Widodo. 
Table 3. Frequency of derivational prefix and suffix in Joko Widodo's Speech

\begin{tabular}{|c|c|c|c|c|}
\hline \multirow{4}{*}{ Rank Order } & \multicolumn{4}{|c|}{ Affixes } \\
\hline & \multicolumn{2}{|c|}{ Prefix } & \multicolumn{2}{|c|}{ Suffix } \\
\hline & Full Collection & & Full Cc & \\
\hline & $\mathrm{n}=11$ & Frequency & $\mathrm{n}=56$ & Frequency \\
\hline 1 & $\mathrm{Be}-$ & 2 & -ion & 14 \\
\hline 2 & Bud- & 2 & -ing & 7 \\
\hline 3 & In- & 2 & $-\mathrm{al}$ & 6 \\
\hline 4 & Infra- & 1 & -ity & 6 \\
\hline 5 & Capa- & 1 & -ment & 3 \\
\hline 6 & Net- & 1 & -tive & 3 \\
\hline 7 & $\mathrm{Al}-$ & 1 & $-n$ & 2 \\
\hline 8 & Un- & 1 & -ine & 2 \\
\hline 9 & & & -ed & 2 \\
\hline 10 & & & -ple & 2 \\
\hline 11 & & & -men & 1 \\
\hline 12 & & & -ce & 1 \\
\hline 13 & & & -or & 1 \\
\hline 14 & & & -ice & 1 \\
\hline 15 & & & -ate & 1 \\
\hline 16 & & & $-1 y$ & 1 \\
\hline 17 & & & -ation & 1 \\
\hline 18 & & & - man & 1 \\
\hline 19 & & & -er & 1 \\
\hline
\end{tabular}

From the result above, the most dominant derivational affixes in the video of Joko Widodo Speech at APEC CEO Summit Asian Pacific is the $b e$ - for prefix and for suffix is -ing on analyzing Fromkin's theory.

Then the other mixing data of each level can be seen from the classification of the data below: 
Table 4. Frequency of inflectional suffix in Joko Widodo's Speech

\begin{tabular}{clc|}
\hline Rank Order & Full Collection & Suffix \\
& $\mathrm{n}=66$ & \\
\hline 1 & -s & Frequency \\
\hline 2 & -es & 51 \\
3 & -ed & 7 \\
4 & -ing & 5 \\
5 & -er & 2 \\
\hline
\end{tabular}

Based on the data above, the result of the analysis by using Fromkin's theory in classifying the inflectional morphemes that suffix -ing is the most dominant of inflectional suffix in the video of Joko Widodo Speech at APEC CEO Summit Asian Pacific.

\section{E. RESULT}

Referring to the occurrence frequency of derivational and inflectional morphemes on Joko Widodo's speech, there are some processes of derivational and inflectional morphemes from one variation to another types. Viewed from linguistic points of view this research is concerned with the study of morphology. This is the way of attaching any affixes to the base such as in derivational morphemes, there were 8 formations, that were noun to adjective, verb to noun, adjective to the adverb, noun to verb, adjective to the noun, verb to the adjective, noun to noun and adjective to adjective. In the inflectional morphemes, there were formation of noun to noun, formation of verb to verb, and formation of adjective to adjective.

So far from having discussed and analyzed the data, It was also shown that there are some different types of derivational and inflectional affixes, there were prefixes like: be-, bud-, in-, infra-, capa-, net-al-, and un-. Suffixes like:-ion, -ing, -al, -ity, -ment, - 
tive, -n, -ine, -ed, -ple, -men, -ce, -or, -ce, ation, -man,- er, -s, -es. These are the different types of derivational and inflectional affixes from speech of Joko Widodo. The high frequency prefix of derivational morpheme was $b e-$, bud-, in- and the high frequency suffix of derivational morpheme was -ion while the high frequency suffix of inflectional morpheme was $-s$.

The current research aims to determine what is the occurrence frequency and process of derivational and inflectional morphemes. Based on the result findings on the analysis of derivational and inflectional on Joko Widodo's speech and its description, some points can be drawn in this research.

1. From the data analysis, the findings of the study prove that from 135 words, the most frequently found is 67 words derivation (50.37\%) which is 57 derivation words that change grammatical classes. The classification as follows: Noun Derivation: -man, -ation, -ity, -ion, -ing, -ment, -ice bud-, in-, net-. Adjective Derivation: -n, -al, -ive, -ing, -ed, un-. Verb Derivation are-ce, -ity, -ine, -ate, in, in-. Adverb derivation found -ly, al-. There were 10 words derivation without changing the grammatical class by attaching some affixes, such as -man, -ple, be, infra-, capa-,-er for Noun to Noun, Adjective to Adjective only found -al. While, the amount of inflectional affixes is 66 words (49.63\%) which frequently found is $-s$ plural by 55 words, - $e d$ for past tense by 4 words, -ing for progressive 3 words, $-s$ third person singular by 3 words, -er for comparative only found 1 word.

2. There are some processes of derivation which change grammatical classes such as adjective to a noun, the verb to noun, noun to adjective, verb to the adjective, noun to verb, adjective to an adverb, while for derivation without changing grammatical classes are noun to noun and adjective to the adjective. There are five kinds of Inflectional Affixes are occurred in this research.for verb forms such as $-s$ for plural, $-s$ for third-person singular, -ing progressive, -ed for past tense, and adjective form like -er for comparative. 


\section{F. REFERENCES}

Abdullah, M. A. (2016). The Use Of Inflectional Morphemes By Kewaiti EFL Learners. English language and literature studies, 6 (3) , 32. http://dx.doi.org/10.5539/ells.v6n3p32.

APEC. (2014). Joko Widodo, President of Indonesia, at the APEC CEO Summit. Beijing, China: https://www.youtube.com/watch?v=Lo2jx_IFAoU\&t=137s.

Aryati, M. S. (2014). An Analysis Of Derivational Affixes in the Land of Five Towers Novel By A. Fuadi Translated By Angie Kilbane.Thesis. Publihed. English Education Department Teacher Training and Education Faculty. Kudus: Muria Kudus University.

Astuti, P. (2018). A Morphological Analysis Of Derivational Affixes In The Video Of Obama"s Speech About Back To School Events 2009. Thesis. Published. English Education Department Teacher Training and Education Faculty. Salatiga: State Institute For Islamic Studies (Iain) Salatiga.

Bauer, L. (1998). Introducing Linguistic Morphology. Edinburgh: Edinburgh University Press.

Booij, G. (2007). The Grammar Of Word (An Introduction To Morphology) (Second Edition). Oxford New York: Oxford University Press Inc.

Candrasari, R. (2018). "Morphological Process of Devayan: An Analysis of Morphological Tipology", Proceedings of MICoMS 2017 (Emerald Reach Proceedings Series, Vol. 1), Emerald Publishing Limited, Bingley, pp. 2733. htps://doi.org/10.1108/978-1-78756-793-1-00045

Carlos, J. Alvarez., Mabel, Urrutia., Alberto, Domínguez., and Rosa, Sánchez-Casas. (2010). Processing inflectional and derivational morphology: Electrophysiologicalevidence from Spanish February 2011 Neuroscience Letters 490(1):6-10DOI:10.1016/j.neulet.2010.12.015.

Carlisle, J. F., \& Fleming, J. (2003). Lexical processing of morphologically complex words in the elementary years. Scientific Studies of Reading, 7(3), 239-253. DOI:10.1207/ S1532799XSSR0703_3.

Carlisle, J. F. (2004). Morphological processes that influence learning to read. In A. Stone, E. R. Silliman, B. Ehren, \& K. Apel (Eds.), Handbook of language and literacy: Development and disorders (pp. 318-339). New York, NY: Guilford.

Creswell, J. (1994). Research Design Qualitative and Quantitative Approaches. New York: Thousand Oaks: SAGE Publications Inc. 
D’Sims, M. H. (2010). Understanding Morphology. London: Hodder Education, a Hachette Company, British Library Cataloging.

Fraenkel, J. R. (2009). How To Design and Evaluate Research in Education, (7th Ed). New York: Mcgraw-Hill.

Goodwin, A. P., Petscher, Y., Carlisle, J. F., \& Mitchell, A. M. (2017). Exploring the dimensionality of morphological knowledge for adolescent readers. Journal of Research in Reading, 40(1), 91-117, DOI: 10.1111/1467-9817.12064.

Hamka. (2014). Morphology and analysis. Journal of English education, 02 (01), 5. https://doi.org/10.24952/ee.v2i1.112.

Holly B. Lane, Linda Gutlohn \& Wilhelmina van Dijk (2019) Morpheme Frequency in Academic Words: Identifying High-Utility Morphemes for Instruction, Literacy Research and Instruction, 58:3, 184-209, DOI: 10.1080/19388071.2019.1617375.

Jack Fraenkel, N. W. (2012). How to Design and Evaluate Research in Education. New York: McGraw-Hill.

Katamba, F. (1993). Morphology.Great Britain: The Macmillan Limited.

Kim, C. (2013). Vocabulary Acquisition With Affixation: Learning English Words Based on Prefixes \& Suffixes. Second Language Studies, 31 (2), 43. https://www.hawaii.edu/sls/wp-content/uploads/2014/09/Kim-Cholo.pdf.

Kristoffersen, Kristian, Emil (2011). Inflectional morphology in cri du chat syndrome - A case study https://www.researchgate.net/journal/Clinical-LinguisticsPhonetics-1464-5076 26(2):120-34

Lieber, R. (2009). Introduction to Morphology. Cambridge: Cambridge University Press.

Mark, Aronoff, K. F. (2011). What Is Morphology? Oxford: Blackwell, Publishing Ltd.

Mathew B.Miles, A. M. (2014). Qualitative Data Analysis. USA: Sage Publication.

Latief, Mohammad, Adnan, J. A. (2016). Introduction To Morphology And Syntax. . Banten: Universitas Terbuka- Kementerian Riset dan Pendidikan Tinggi.

Nandito, K. (2016). Derivational and Inflectional Morphemes. International Journal of Engineering, It \& Scientific Research. 2 (1), 22.

Nurjannah, S. Y. (2018). Affixation Of Derivational And Inflectional Process In Narrative Text Entitled The Ugly Duckling. Professional Journal Of English 
Education

01

(03),

310.

https://journal.ikipsiliwangi.ac.id/index.php/project/article/view/1217.

Pala, P. S. (2004). Text, Speech, and Dialogue. United States of America: SpringerVerlag United States.

Setiowati, N. E. (2014). The Analysis Of Derivational And Inflectional Morphemes. Surakarta: Muhammadiyah University Of Surakarta.

Sherman, H. (2020). Joko widodo as President of Indonesia. Lampung: (On-Line) http://www.com/boography/joko-.

Sims, M. H. (2010). Understanding Morphology (Understanding Language Series). London: Hodder Education, An Hachette Company.

Tighe, E. L., \& Schatschneider, C. (2015). Exploring the dimensionality of morphological awareness and its relations to vocabulary knowledge in adult basic education students. Reading Research Quarterly, 50(3), 293-311. DOI:10.1002/rrq.102.

Victoria, Fromkin, A. (2017). An Introduction To Language. Canada: Nelson Education.

Yule, G. (2014). The Study of Language. England: Cambridge University Press. 